\title{
A DFT STUDY OF THE RELATIONSHIPS BETWEEN ELECTRONIC STRUCTURE AND PERIPHERAL BENZODIAZEPINE RECEPTOR AFFINITY IN A GROUP OF $N, N$-DIALKYL-2-PHENYLINDOL-3- YLGLYOXYLAMIDES
}

\author{
JUAN S. GÓMEZ-JERIA \\ Universidad de Chile, Facultad de Ciencias, Departamento de Química. Casilla 653 Santiago 21, Chile
}

(Received: March 25, 2010 - Accepted: July 12, 2010)

\begin{abstract}
We present here the results of a Density Functional Theory study of the relationships between electronic structure and peripheral benzodiazepine receptor affinity for a group of $N, N$-dialkyl-2-phenylindol-3-ylglyoxylamide derivatives. As expected for a receptor that evolved over many millions of years, the interaction is charge- and orbital-controlled because it involves net charges and reactivity indices from definite molecular orbitals. The conditions for high receptor affinity are obtained and commented on. A partial pharmacophore model is suggested and discussed. This is the first time that an all-electron calculation combined with a model-based method is employed in QSAR studies.
\end{abstract}

Keywords: Density Functional Theory, Fukui indices, superdelocalizabilities, structure-activity relationships, receptor affinity, peripheral benzodiazepine receptor.

\section{INTRODUCTION}

Benzodiazepines (Bz) were introduced into clinical practice in the 1950 s and they were received as efficacious minor tranquilizers, largely devoid of unwanted side effects, in contrast to the barbiturates and similar drugs that they largely superseded. Bz are the most commonly prescribed minor tranquilizers, also known as anxiolytics and hypnotics. Today there is little doubt of the therapeutic efficacy of $\mathrm{Bz}$ in reducing anxiety, inducing sleep and quelling panic symptoms. Their action occurs through their binding to a site in the $\mathrm{GABA}_{\mathrm{A}}$ receptor-benzodiazepine receptor-chloride ion channel complex (called BzR here), located in several regions of the Central Nervous System (CNS).

There is another distinct high affinity $\mathrm{Bz}$ binding site, the translocator protein (TSPO), also called the Peripheral Benzodiazepine Receptor (PBR). In spite of its original discovery in the periphery, the PBR is also present in the CNS where it is primarily located in glial cells, with highest densities in the olfactory bulb, choroid plexus, and the ependymal lining of the ventricles. PBRs have been associated with numerous biological functions such as the regulation of apoptosis, regulation of cell proliferation, stimulation of steroidogenesis, immunomodulation, porphyrin transport, heme biosynthesis, anion transport and regulation of mitochondrial functions. It is likely that the use of specific PBR ligands to modulate PBR activity may have potential therapeutic applications for the management of a large spectrum of different indications including cancer, auto-immune, infectious and neurodegenerative diseases.

Recently, Primofiore et al. ${ }^{1}$ synthetized a series of $N, N$-dialkyl-2phenylindol-3-ylglyoxylamide (DPY) derivatives showing a wide range of affinities for the PBR and a low inhibitory action on $\left[{ }^{3} \mathrm{H}\right]$ flumazenil specific binding to the central Bz receptor. Given the above possible therapeutic use of PBR ligands we present here the results of a Density Functional Theory study of the relationships between electronic structure and PBR receptor affinity for the abovementioned molecules.

\section{METHODS, MODELS AND CALCULATIONS.}

As the method employed here has been discussed in great detail in this Journal ${ }^{2-6}$ and elsewhere ${ }^{7-14}$, we shall only present a brief sketch here. Within the Klopman-Peradejordi-Gómez (KPG) model $^{15}$, and for a group of molecules having a common skeleton and interacting with the same receptor, it can be shown that the affinity constant $(\mathrm{K})$ can be expressed as ${ }^{15}$ :

$$
\log \mathrm{K}_{\mathrm{i}}=\mathrm{a}+\mathrm{b} \log \mathrm{M}_{\mathrm{Di}}+\mathrm{c} \log \mathrm{s}_{\mathrm{Di}}+\mathrm{d} \log \left(\mathrm{I}_{1} \mathrm{I}_{2} \mathrm{I}_{3}\right)+e \mathrm{DE}_{\mathrm{i}}
$$

where $\mathrm{a}, \mathrm{b}, \mathrm{c}, \mathrm{d}$ and e are constants, D refers to the DPI molecule, $\sigma$ is the symmetry number, $\mathrm{M}$ the DPI's molecular mass, $\mathrm{I}_{1} \mathrm{I}_{2} \mathrm{I}_{3}$ is the product of the three moments of inertia about the three principal axes of rotation of the DPIs, and $\triangle \mathrm{E}$ is the DPI-PBR interaction energy. The interaction energy, $\Delta \mathrm{E}$, cannot be determined directly, either due to the size of the receptor or to lack of knowledge of its molecular structure. Nevertheless, when we consider a drugreceptor interaction in which no covalent bonds are formed, we can employ

$$
\begin{gathered}
\Delta \mathrm{E}=\mathrm{W}+\sum_{\mathrm{i}}\left[\mathrm{E}_{\mathrm{i}} \mathrm{Q}_{\mathrm{i}}+\mathrm{X}_{\mathrm{i}} \mathrm{S}_{\mathrm{i}}^{\mathrm{E}}+\mathrm{G}_{\mathrm{i}} \mathrm{S}_{\mathrm{i}}^{\mathrm{N}}\right]+\sum_{\mathrm{i}} \sum_{\mathrm{m}}\left[\mathrm{H}_{\mathrm{i}}(\mathrm{m}) \mathrm{F}_{\mathrm{i}}(\mathrm{m})+\mathrm{J}_{\mathrm{i}}(\mathrm{m}) \mathrm{S}_{\mathrm{i}}^{\mathrm{E}}(\mathrm{m})\right]+ \\
\sum_{\mathrm{i}} \sum_{\mathrm{m}^{\prime}}\left[\mathrm{R}_{\mathrm{i}}\left(\mathrm{m}^{\prime}\right) \mathrm{F}_{\mathrm{i}}\left(\mathrm{m}^{\prime}\right)+\mathrm{T}_{\mathrm{i}}\left(\mathrm{m}^{\prime}\right) \mathrm{S}_{\mathrm{i}}^{\mathrm{N}}\left(\mathrm{m}^{\prime}\right)\right]
\end{gathered}
$$

Perturbation Theory to obtain the following expression:

where $\mathrm{W}, \mathrm{E}, \mathrm{X}, \mathrm{G}, \mathrm{H}, \mathrm{J}, \mathrm{R}$, and $\mathrm{T}$ are constants. $\mathrm{Q}_{\mathrm{i}}$ is the net charge of atom i. $F_{i}(m)$ and $F_{i}\left(m^{\prime}\right)$ are, respectively, the Fukui index of atom $i$ associated to the $\mathrm{m}$-th occupied $\mathrm{MO}$ and the $\mathrm{m}^{\mathrm{T}}$-th empty $\mathrm{MO} . \mathrm{S}^{\mathrm{E}}{ }^{\mathrm{E}}$ and $\mathrm{S}_{\mathrm{i}}^{\mathrm{N}}$ are, respectively, the total atomic electrophilic (ESD) and nucleophilic superdelocalizabilities (NSD) of atom i defined as:

$$
\mathrm{S}_{\mathrm{i}}^{\mathrm{E}}=\sum_{\mathrm{m}} \frac{\mathrm{F}_{\mathrm{i}, \mathrm{m}}}{\mathrm{E}_{\mathrm{m}}}
$$

where the summation on $m$ is over the occupied MOs energies $\left(E_{m}\right)$ and their associated Fukui index of atom $\mathrm{i}\left(\mathrm{F}_{\mathrm{i}, \mathrm{m}}\right)$, and:

$$
\mathrm{S}_{\mathrm{i}}^{\mathrm{N}}=\sum_{\mathrm{n}} \frac{\mathrm{F}_{\mathrm{i}, \mathrm{n}}}{\mathrm{E}_{\mathrm{n}}}
$$

where the summation on $\mathrm{n}$ is now over the virtual MO's energies $\left(\mathrm{E}_{\mathrm{n}}\right)$ and their associated Fukui index of atom i $\left(\mathrm{F}_{\mathrm{i}, \mathrm{n}}\right)$.

Given that in some atomic centers the first non-zero orbital superdelocalizabilities may play a fundamental role in the interaction with the receptor, we have introduced the following indices:

$$
\mathrm{S}_{\mathrm{i}}^{\mathrm{E}^{*}}=\frac{\mathrm{F}_{\mathrm{i}, \mathrm{oc}}^{*}}{\mathrm{E}_{\mathrm{oc}}^{*}}
$$

where $\mathrm{F}_{\mathrm{i}, \mathrm{oc}}^{*}$ is now the first non-zero Fukui index of atom $\mathrm{i}$ in the region of occupied MOs and $\mathrm{E}^{*}$ is the associated MO energy ${ }^{16}$. A similar expression holds for the first non-zero atomic nucleophilic superdelocalizability. Fukui indices are simply the total gross populations as defined by Mulliken.

These reactivity indices can be directly interpreted. Within a given molecule, $S_{i}{ }^{E}$ represents the relative capacity to transfer electrons to an electron-deficient center and $\mathrm{S}_{\mathrm{i}}^{\mathrm{N}}$ represents the relative capacity to accept electrons. $\mathrm{F}_{i}(\mathrm{~m})$ is the Fukui function of atom $\mathrm{i}$ at MO $\mathrm{m}$ (or $\mathrm{m}$ '). The whole family of Fukui indices has been employed in our group for more than 20 years in structure-activity studies ${ }^{2-14}$. 
Regarding the products of the moments of inertia, they can be expressed in a first approximation as:

$$
\log \left(I_{1} I_{2} I_{3}\right)=\sum_{t} \sum_{i} m_{i, t} R_{i, t}^{2}=\sum_{t} O_{t}
$$

where the summation over $t$ is over the different substituents of the molecule, $m_{i, t}$ is the mass of the $i$-th atom belonging to the $r$-th substituent, and $R_{i, t}$ is its distance to the atom to which the substituent is attached. We have called the right side of equation 6 the substituent's orientational parameter (OP).

Inserting equations 6 and 2 into equation 1 we obtain a relationship expressing the variation of a biological activity with the variation of the reactivity indices of atoms of the drug molecules only. We also assume that the molecules interact with their target through a common skeleton, the substituents only modulating the electronic properties of that skeleton. The KPG approach has produced excellent results for very different biologically active molecules (see Refs. 2-15). We must stress that the final equation must have a mathematical solution because it belongs to the family of model-based methods ${ }^{17}$. The difficulty is that the number of molecules is generally less than the number of unknown quantities. For this reason statistical analysis is employed to find the best solution.

The selected molecular systems are shown in Fig. 1 and Table 1. The values for the DPI-BPR affinity were taken from the literature ${ }^{1}$.

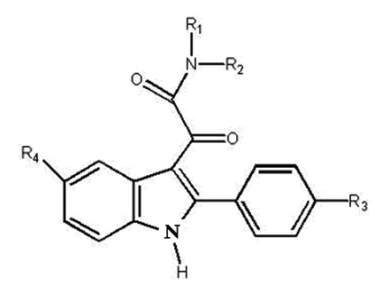

Figure 1. General formula for the $N, N$-dialkyl-2-phenylindol-3ylglyoxylamides.

Table 1. Structure and experimental affinities of the selected $N, N$-dialkyl2-phenylindol-3-ylglyoxylamides for the Peripheral Bz Receptor.

\begin{tabular}{|c|c|c|c|c|c|}
\hline Molecule & $\mathrm{R}_{1}$ & $\mathrm{R}_{2}$ & $\mathrm{R}_{3}$ & $\mathrm{R}_{4}$ & $\begin{array}{c}\log K_{i} \\
(n M)\end{array}$ \\
\hline 1 & $\left(\mathrm{CH}_{2}\right)_{2} \mathrm{CH}_{3}$ & $\mathrm{H}$ & $\mathrm{H}$ & $\mathrm{H}$ & 2.91 \\
\hline 2 & $\left(\mathrm{CH}_{2}\right)_{3} \mathrm{CH}_{3}$ & $\mathrm{H}$ & $\mathrm{H}$ & $\mathrm{H}$ & 3.07 \\
\hline 3 & $\mathrm{CH}_{2} \mathrm{CH}_{3}$ & $\mathrm{CH}_{2} \mathrm{CH}_{3}$ & $\mathrm{H}$ & $\mathrm{H}$ & 1.63 \\
\hline 4 & $\left(\mathrm{CH}_{2}\right)_{2} \mathrm{CH}_{3}$ & $\left(\mathrm{CH}_{2}\right)_{2} \mathrm{CH}_{3}$ & $\mathrm{H}$ & $\mathrm{H}$ & 1.09 \\
\hline 5 & $\left(\mathrm{CH}_{2}\right)_{3} \mathrm{CH}_{3}$ & $\left(\mathrm{CH}_{2}\right)_{3} \mathrm{CH}_{3}$ & $\mathrm{H}$ & $\mathrm{H}$ & 0.88 \\
\hline 6 & $\left(\mathrm{CH}_{2}\right)_{4} \mathrm{CH}_{3}$ & $\left(\mathrm{CH}_{2}\right)_{4} \mathrm{CH}_{3}$ & $\mathrm{H}$ & $\mathrm{H}$ & 1.20 \\
\hline 7 & $\left(\mathrm{CH}_{2}\right)_{5} \mathrm{CH}_{3}$ & $\left(\mathrm{CH}_{2}\right)_{5} \mathrm{CH}_{3}$ & $\mathrm{H}$ & $\mathrm{H}$ & 0.15 \\
\hline 8 & $\mathrm{CH}\left(\mathrm{CH}_{3}\right)_{2}$ & $\mathrm{CH}\left(\mathrm{CH}_{3}\right)_{2}$ & $\mathrm{H}$ & $\mathrm{H}$ & 2.03 \\
\hline 9 & $\mathrm{CH}\left(\mathrm{CH}_{3}\right) \mathrm{CH}_{2} \mathrm{CH}_{3}$ & $\mathrm{CH}\left(\mathrm{CH}_{3}\right) \mathrm{CH}_{2} \mathrm{CH}_{3}$ & $\mathrm{H}$ & $\mathrm{H}$ & 1.23 \\
\hline 10 & $-\left(\mathrm{CH}_{2}\right)_{4}$ & & $\mathrm{H}$ & $\mathrm{H}$ & 3.38 \\
\hline 11 & $-\left(\mathrm{CH}_{2}\right)_{5-}$ & & $\mathrm{H}$ & $\mathrm{H}$ & 2.82 \\
\hline 12 & $-\left(\mathrm{CH}_{2}\right)_{6-}$ & & $\mathrm{H}$ & $\mathrm{H}$ & 1.52 \\
\hline 13 & $\left(\mathrm{CH}_{2}\right)_{2} \mathrm{CH}_{3}$ & $\left(\mathrm{CH}_{2}\right)_{2} \mathrm{CH}_{3}$ & $\mathrm{Cl}$ & $\mathrm{H}$ & 0.67 \\
\hline 14 & $\left(\mathrm{CH}_{2}\right)_{3} \mathrm{CH}_{3}$ & $\left(\mathrm{CH}_{2}\right)_{3} \mathrm{CH}_{3}$ & $\mathrm{Cl}$ & $\mathrm{H}$ & 0.00 \\
\hline 15 & $\left(\mathrm{CH}_{2}\right)_{5} \mathrm{CH}_{3}$ & $\left(\mathrm{CH}_{2}\right)_{5} \mathrm{CH}_{3}$ & $\mathrm{Cl}$ & $\mathrm{H}$ & -0.26 \\
\hline 16 & $\left(\mathrm{CH}_{2}\right)_{2} \mathrm{CH}_{3}$ & $\left(\mathrm{CH}_{2}\right)_{2} \mathrm{CH}_{3}$ & $\mathrm{~F}$ & $\mathrm{H}$ & 0.63 \\
\hline 17 & $\left(\mathrm{CH}_{2}\right)_{3} \mathrm{CH}_{3}$ & $\left(\mathrm{CH}_{2}\right)_{3} \mathrm{CH}_{3}$ & $\mathrm{~F}$ & $\mathrm{H}$ & 0.38 \\
\hline 18 & $\left(\mathrm{CH}_{2}\right)_{5} \mathrm{CH}_{3}$ & $\left(\mathrm{CH}_{2}\right)_{5} \mathrm{CH}_{3}$ & $\mathrm{~F}$ & $\mathrm{H}$ & -0.43 \\
\hline 19 & $\left(\mathrm{CH}_{2}\right)_{2} \mathrm{CH}_{3}$ & $\left(\mathrm{CH}_{2}\right)_{2} \mathrm{CH}_{3}$ & $\mathrm{CH}_{3}$ & $\mathrm{H}$ & 0.74 \\
\hline
\end{tabular}

\begin{tabular}{|l|l|l|l|l|l|}
\hline 20 & $\left(\mathrm{CH}_{2}\right)_{3} \mathrm{CH}_{3}$ & $\left(\mathrm{CH}_{2}\right)_{3} \mathrm{CH}_{3}$ & $\mathrm{CH}_{3}$ & $\mathrm{H}$ & 0.58 \\
\hline 21 & $\left(\mathrm{CH}_{2}\right)_{5} \mathrm{CH}_{3}$ & $\left(\mathrm{CH}_{2}\right)_{5} \mathrm{CH}_{3}$ & $\mathrm{CH}_{3}$ & $\mathrm{H}$ & 0.20 \\
\hline 22 & $\left(\mathrm{CH}_{2}\right)_{2} \mathrm{CH}_{3}$ & $\left(\mathrm{CH}_{2}\right)_{2} \mathrm{CH}_{3}$ & $\mathrm{H}$ & $\mathrm{Cl}$ & 0.45 \\
\hline 23 & $\left(\mathrm{CH}_{2}\right)_{3} \mathrm{CH}_{3}$ & $\left(\mathrm{CH}_{2}\right)_{3} \mathrm{CH}_{3}$ & $\mathrm{H}$ & $\mathrm{Cl}$ & 0.69 \\
\hline 24 & $\left(\mathrm{CH}_{2}\right)_{5} \mathrm{CH}_{3}$ & $\left(\mathrm{CH}_{2}\right)_{5} \mathrm{CH}_{3}$ & $\mathrm{H}$ & $\mathrm{Cl}$ & 1.77 \\
\hline 25 & $\left(\mathrm{CH}_{2}\right)_{2} \mathrm{CH}_{3}$ & $\left(\mathrm{CH}_{2}\right)_{2} \mathrm{CH}_{3}$ & $\mathrm{Cl}$ & $\mathrm{Cl}$ & -0.21 \\
\hline 26 & $\left(\mathrm{CH}_{2}\right)_{3} \mathrm{CH}_{3}$ & $\left(\mathrm{CH}_{2}\right)_{3} \mathrm{CH}_{3}$ & $\mathrm{Cl}$ & $\mathrm{Cl}$ & 0.28 \\
\hline 27 & $\left(\mathrm{CH}_{2}\right)_{5} \mathrm{CH}_{3}$ & $\left(\mathrm{CH}_{2}\right)_{5} \mathrm{CH}_{3}$ & $\mathrm{Cl}$ & $\mathrm{Cl}$ & 0.76 \\
\hline
\end{tabular}

All the calculations were performed with the Gaussian 98 package $^{18}$. Full geometry optimization was carried out at the B3LYP/6-31G* level. The necessary information to calculate the reactivity indices was extracted from the Gaussian output files with software written by us.

The statistical fitting of the final equation was performed by means of a stepwise regression technique with the inhibitory activities as dependent variables and the static reactivity indices of the atoms belonging to a common skeleton as independent variables. Statistica software was used ${ }^{19}$. The common skeleton is depicted in Figure 2. We added the OP of substituents located at positions $R_{1}$ and $R_{2}$ of the common skeleton (see Figure 2). Their numerical values are shown in Table 2 .

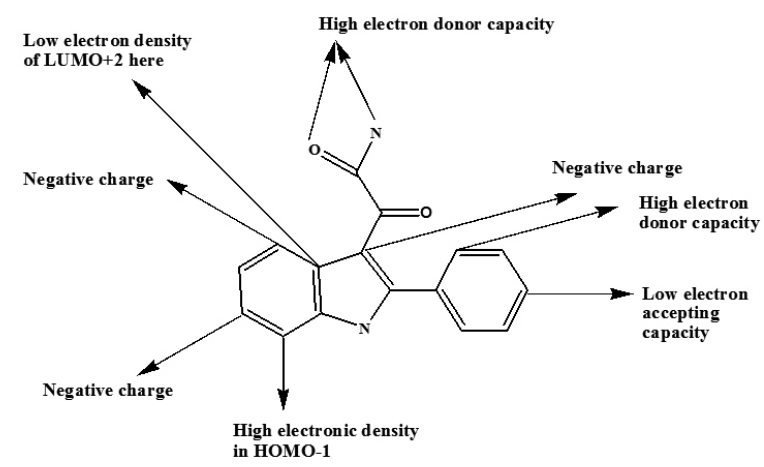

Figure 2. Common skeleton for the $N, N$-dialkyl-2-phenylindol-3ylglyoxylamides.

Table 2. Orientational parameters (uma $\AA^{2}$ ).

\begin{tabular}{|c|c|}
\hline Substituent & Orient. Factor \\
\hline $\mathrm{H}$ & 1.2 \\
\hline$\left(\mathrm{CH}_{2}\right)_{2} \mathrm{CH}_{3}$ & 366.33 \\
\hline$\left(\mathrm{CH}_{2}\right)_{3} \mathrm{CH}_{3}$ & 737.31 \\
\hline $\mathrm{CH}_{2} \mathrm{CH}_{3}$ & 141.1 \\
\hline$\left(\mathrm{CH}_{2}\right)_{4} \mathrm{CH}_{3}$ & 1323.74 \\
\hline$\left(\mathrm{CH}_{2}\right)_{5} \mathrm{CH}_{3}$ & 2144.64 \\
\hline $\mathrm{CH}\left(\mathrm{CH}_{3}\right)_{2}$ & 218.42 \\
\hline $\mathrm{CH}\left(\mathrm{CH}_{3}\right) \mathrm{CH}_{2} \mathrm{CH}_{3}$ & 386.3 \\
\hline$-\left(\mathrm{CH}_{2}\right)_{4-}$ & 362.51 \\
\hline$-\left(\mathrm{CH}_{2}\right)_{5-}$ & 545.49 \\
\hline$-\left(\mathrm{CH}_{2}\right)_{6-}$ & 791 \\
\hline
\end{tabular}

\section{RESULTS}

The best equation obtained was:

$\log K_{i}=-180.88-694.73 \mathrm{~F}_{6}(\mathrm{LUMO}+2)-0.04 S_{14}^{N}-17.88 \mathrm{~S}_{18}^{\mathrm{E}^{*}}-$

$-0.98 S_{11}^{\mathrm{E}^{*}}-0.13 \mathrm{~S}_{19}^{\mathrm{E}^{*}}+0.05 S_{16}^{N}(\mathrm{LUMO}+2)+9.23 S_{13}^{N}(\mathrm{LUMO})-$

$-437.13 \mathrm{Q}_{1}-446.58 \mathrm{Q}_{9}+63.6 F_{4}(\mathrm{HOMO}-1)+89.48 F_{19}(\mathrm{HOMO})-250.32 \mathrm{Q}$ 
with $\mathrm{n}=27, \mathrm{R}^{2}=0.98, \mathrm{SD}=0.22$ and $\mathrm{F}(12,14)=50.35(\mathrm{p}<0.000001)$. The high $\mathrm{F}$ value shows that Eq. 6 is statistically significant as a whole. In Table 3 we show the Student $t$ test for the variables in Eq. 6. Table 4 shows the experimental and calculated values of $\log K_{\text {i: }}$.

Table 3. Student $\mathrm{t}$ test results for the variables in $\mathrm{Eq} 6$.

\begin{tabular}{|c|c|c|}
\hline Variable & $\mathrm{t}$ & $\mathrm{p}$ \\
\hline $\mathrm{F}_{6}(\mathrm{LUMO}+2)$ & $-7,81$ & $1,80 \mathrm{E}-06$ \\
\hline $\mathrm{S}_{14}{ }^{\mathrm{N}}$ & $-9,61$ & $1,53 \mathrm{E}-07$ \\
\hline $\mathrm{S}_{18}{ }^{\mathrm{E}^{*}}$ & $-9,03$ & $3,27 \mathrm{E}-07$ \\
\hline $\mathrm{S}_{11}{ }^{\mathrm{E}^{*}}$ & $-12,22$ & $7,37 \mathrm{E}-09$ \\
\hline $\mathrm{S}_{19}{ }^{\mathrm{E}^{*}}$ & $-2,04$ & $6,07 \mathrm{E}-02$ \\
\hline $\mathrm{S}_{16}{ }^{\mathrm{N}}(\mathrm{LUMO}+2)$ & 2,05 & $5,95 \mathrm{E}-02$ \\
\hline $\mathrm{S}_{13}{ }^{\mathrm{N}}(\mathrm{LUMO})$ & 1,91 & $7,64 \mathrm{E}-02$ \\
\hline $\mathrm{Q}_{1}$ & $-8,80$ & $4,42 \mathrm{E}-07$ \\
\hline $\mathrm{Q}_{9}$ & $-7,89$ & $1,61 \mathrm{E}-06$ \\
\hline $\mathrm{F}_{4}(\mathrm{HOMO}-1)$ & 6,55 & $1,30 \mathrm{E}-05$ \\
\hline $\mathrm{F}_{19}(\mathrm{HOMO})$ & 6,31 & $1,94 \mathrm{E}-05$ \\
\hline $\mathrm{Q}_{3}$ & $-4,95$ & $2,13 \mathrm{E}-04$ \\
\hline
\end{tabular}

Table 4. Experimental and calculated values for $\log K_{\mathrm{i}}(\mathrm{nM})$.

\begin{tabular}{|c|c|c|}
\hline Molecule & $\log K_{\mathrm{i}} \operatorname{Exp}$ & Log $K_{\mathrm{i}}$ Calc. \\
\hline 1 & 2,91 & 3,13 \\
\hline 2 & 3,07 & 2,90 \\
\hline 3 & 1,63 & 1,63 \\
\hline 4 & 1,09 & 1,20 \\
\hline 5 & 0,88 & 0,54 \\
\hline 6 & 1,20 & 1,16 \\
\hline 7 & 0,15 & 0,40 \\
\hline 8 & 2,03 & 2,02 \\
\hline 9 & 1,23 & 1,23 \\
\hline 10 & 3,38 & 3,37 \\
\hline 11 & 2,82 & 2,76 \\
\hline 12 & 1,52 & 1,58 \\
\hline 13 & 0,67 & 0,70 \\
\hline 14 & 0,00 & $-0,19$ \\
\hline 15 & $-0,26$ & $-0,08$ \\
\hline 16 & 0,63 & 0,63 \\
\hline 17 & 0,38 & 0,08 \\
\hline 18 & $-0,43$ & $-0,17$ \\
\hline 19 & 0,74 & 0,87 \\
\hline 20 & 0,58 & 0,46 \\
\hline 21 & 0,20 & 0,29 \\
\hline 22 & 0,45 & 0,37 \\
\hline 23 & 0,69 & 0,91 \\
\hline 24 & 1,77 & 1,62 \\
\hline 25 & $-0,21$ & $-0,12$ \\
\hline 26 & 0,28 & 0,15 \\
\hline 27 & 0,76 & 0,74 \\
\hline
\end{tabular}

DISCUSSION

Equation 6 indicates that a relationship exists between the variation of $\log \mathrm{K}_{\mathrm{i}}$ and the variation of the values of a set of local reactivity indices belonging to the common skeleton.

A first inspection of this equation indicates that the drug-receptor interaction is charge- and orbital-controlled. This is due to the appearance in the equation of net charges and reactivity indices involving definite molecular orbitals. This is natural if we think that receptors evolved over hundreds of millions of years and, as each one has one or more functions, they must have a very high selectivity for the recognition of their natural ligands.

The structure of equation 6 will provide us with the best possible information about the interaction of these ligands with the receptor. From this information we can build a model, tentative and partial, of sections of the receptor that interact with these molecules. We use the term "partial" because many atomic indices may have constant or almost constant values in the molecules studied here. Therefore, they do not appear in Eq. (6). The first step in the analysis consists in the examination of the results of the Student t-test to detect those variables that are highly relevant in Eq. (6) (see Table 3). From this Table we may note that there are three variables with a $p$ value associated with the test result whose values are too high: $\mathrm{S}_{19} \mathrm{E}^{*}, \mathrm{~S}_{16}{ }^{\mathrm{N}}(\mathrm{LUMO}+2)$ and $\mathrm{S}_{13}{ }^{\mathrm{N}}(\mathrm{LUMO})$. Consequently, for precaution, we discarded them. The second step consists in detecting a high degree of collinearity between the variables of Eq. (6). Knowing that in molecular systems there is always a degree of collinearity between atomic indices belonging to aromatic regions, we have considered that any pair of variables in which the square of the internal correlation coefficient (r) is equal to or greater than 0.6 are collinear. In this case we selected one of them based on the results of the Student $t$ test. For Eq. (6) we found that only $\mathrm{Q}_{1}$ and $\mathrm{S}_{13} \mathrm{~N}(\mathrm{LUMO})$ have $\mathrm{r}^{2}=0.64$. Given that we had already discarded $\mathrm{S}_{13} \mathrm{~N}(\mathrm{LUMO})$ in the previous step, we selected the other variable.

The last step consists in considering the sign of the coefficient of each variable of Eq. (6) and the sign of the variables themselves. This will allow us to suggest the ideal numerical values that the variables of Eq. (6) should have in order to describe a system with high affinity. We must consider that net charges may be positive, negative or zero, Fukui indices may be zero or positive, the total ESD is always negative, orbital ESDs are zero or negative, total NSDs are always positive and that orbital NSDs are zero or positive.

The results of the analysis indicate that a high receptor affinity is associated with the following conditions:

1. Negative values for $\mathrm{Q}_{1}, \mathrm{Q}_{3}$ and $\mathrm{Q}_{9}$.

2. High numerical values for $\mathrm{F}_{4}(\mathrm{HOMO}-1)$ and $\mathrm{F}_{10}(\mathrm{HOMO})$.

3. Small numerical values for $\mathrm{F}_{6}(\mathrm{LUMO})$ and $\mathrm{S}_{14} \mathrm{~N}$.

4. High values for $\mathrm{S}_{18} \mathrm{E}^{*}, \mathrm{~S}_{19}{ }^{\mathrm{E}^{*}}$ and $\mathrm{S}_{1} \mathrm{E}^{*}$.

Figure 3 summarizes the conditions associated with a high receptor affinity. We can see in that figure that the left side of the common skeleton interacts electrostatically with one or more positively charged moieties of the PBR. The region of the $\mathrm{C}(=\mathrm{O})-\mathrm{C}(=\mathrm{O})-\mathrm{N}$ group, together with part of the benzene ring, seem to interact via charge transfer with the receptor. It is necessary to emphasize that some factors that seem to be important do not appear in Eq. 6 . For example molecules 1 and 2 differ only in the size of the $\mathrm{R}_{1}$ substituent but have different receptor affinities. The structures of the $N$-substituents (n-propyl and n-butyl) strongly suggest that their effect on the electronic structure of the nitrogen atom should be the same. If this is true, then the orientational effect of $\mathrm{R}_{1}$ affects the receptor affinity. Such an effect appears in other equations that were not statistically significant. This example clearly shows that the pharmacophore model presented in Fig. 3 is incomplete as is the case in most (if not all) QSAR studies reported in the literature. The only way to get more information about the pharmacophore is by analyzing new sets of analogous molecules interacting with the PBR.

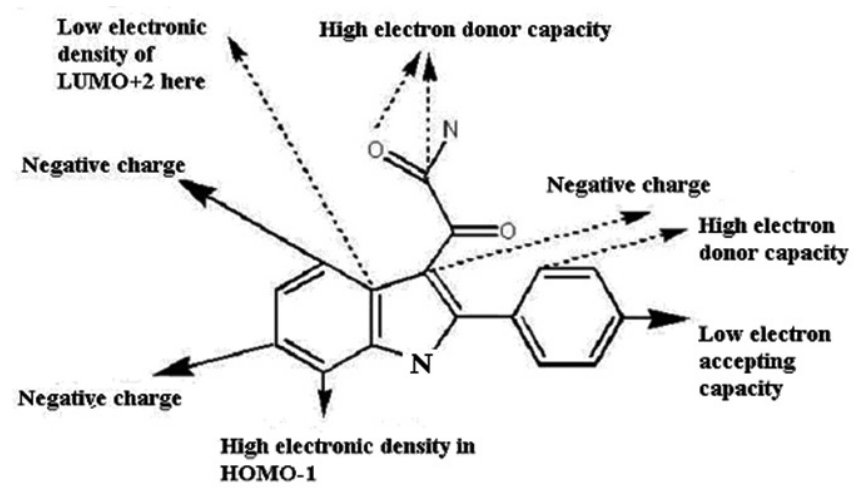

Figure 3. Schematic representation of the results of Eq. 6.

From the theoretical point of view, the most important result is that this study is the first one that obtains QSAR results employing an all-electron 
calculation combined with a model-based method as defined by Martin ${ }^{17}$ (there are some previous published QSAR studies employing all-electron calculations that have not an underlying model-based structure).

I thank Prof. Dr. Bruce Cassels (University of Chile) for helpful comments.

\section{REFERENCES}

1. G. Primofiore, F. Da Settimo, S. Taliani, F. Simorini, M. P. Patrizi, E. Novellino, G. Greco, E. Abignente, B. Costa, B. Chelli, C. Martini, J. Med. Chem. 47 (2004) 1852.

2. J. S. Gómez-Jeria, F. Soto-Morales, J. Rivas, A. Sotomayor, J. Chil. Chem. Soc. 53 (2008) 1382.

3. F. Soto-Morales, J. S. Gómez-Jeria, J. Chil. Chem. Soc. 52 (2007) 1214.

4. J. S. Gómez-Jeria, L.A. Gerli-Candia, S.M. Hurtado, J. Chil. Chem. Soc. 49 (2004) 307.

5. J. S. Gómez-Jeria, M. Ojeda-Vergara, J. Chil. Chem. Soc. 48 (2003) 119.

6. J. S. Gómez-Jeria, L. Lagos-Arancibia, E. Sobarzo-Sánchez, J. Chil. Chem. Soc. 48 (2003) 61.

7. J. S. Gómez-Jeria, Int. J. Quantum Chem. 23 (1983) 1969.

8. J. S. Gómez-Jeria, M. Ojeda-Vergara, Int. J. Quantum Chem. 61 (1997) 997.

9. J. S. Gómez-Jeria, L. Lagos-Arancibia, Int. J. Quantum Chem. 71 (1999) 505 .

10. J. S. Gómez-Jeria, C. Donoso-Espinoza, M. Ojeda-Vergara, Mol. Engn. 5 (1995) 391.

11. J.S. Gómez-Jeria, P. Sotomayor, J. Mol .Struct. (Theochem) 166 (1988) 493.
12. J. S. Gómez-Jeria, D. Morales-Lagos, B. K. Cassels, J. C. SaavedraAguilar, Quant. Struct. Act. Relat. 5 (1986) 153.

13. J.S. Gómez-Jeria, B.K. Cassels, J.C. Saavedra-Aguilar, Eur. J. Med. Chem. 22 (1987) 433.

14. J. S. Gómez-Jeria, F. Soto-Morales, G. Larenas-Gutierrez, Iranian Int. J. Sci. 4 (2003) 151.

15. J. S. Gómez-Jeria in Molecules in Physics, Chemistry and Biology, J.Maruani, Ed. (Kluwer, Dordrecht, 1989), Vol.4, pp.231-251.

16. J. S. Gómez-Jeria, PhD Thesis. Universidad Andrés Bello, Santiago, Chile, 2008.

17. Y. C. Martin, Quantitative Drug Design, Dekker, New York, 1978.

18. Gaussian 98, Revision A.11.3, M. J. Frisch, G. W. Trucks, H. B. Schlegel, G. E. Scuseria, M. A. Robb, J. R. Cheeseman, V. G. Zakrzewski, J. A. Montgomery, Jr., R. E. Stratmann, J. C. Burant, S. Dapprich, J. M. Millam, A. D. Daniels, K. N. Kudin, M. C. Strain, O. Farkas, J. Tomasi, V. Barone, M. Cossi, R. Cammi, B. Mennucci, C. Pomelli, C. Adamo, S. Clifford, J. Ochterski, G. A. Petersson, P. Y. Ayala, Q. Cui, K. Morokuma, N. Rega, P. Salvador, J. J. Dannenberg, D. K. Malick, A. D. Rabuck, K. Raghavachari, J. B. Foresman, J. Cioslowski, J. V. Ortiz, A. G. Baboul, B. B. Stefanov, G. Liu, A. Liashenko, P. Piskorz, I. Komaromi, R. Gomperts, R. L. Martin, D. J. Fox, T. Keith, M. A. Al-Laham, C. Y. Peng, A. Nanayakkara, M. Challacombe, P. M. W. Gill, B. Johnson, W. Chen, M. W. Wong, J. L. Andres, C. Gonzalez, M. Head-Gordon, E. S. Replogle, y J. A. Pople, Gaussian, Inc., Pittsburgh PA, 2002.

19. Statistica 7.0, StatSoft, Inc., Tulsa, OK, USA, 2004. 